\title{
Erratum: Exposure to a youthful circulation rejuvenates bone repair through modulation of $\beta$-catenin
}

Gurpreet S. Baht, David Silkstone, Linda Vi, Puviindran Nadesan, Yasha Amani, Heather Whetstone, Qingxia Wei \& Benjamin A. Alman

Nature Communications 6:7131 doi: 10.1038/ncomms8131 (2015); Published 19 May 2015; Updated 26 Aug 2015

The original version of this Article contained an error in the spelling of circulation in the title of the paper, and in Fig. 1e, a scale bar and arrows were inadvertently omitted. These errors have now been corrected in both the PDF and HTML versions of the article.

(c) This work is licensed under a Creative Commons Attribution 4.0 International License. The images or other third party material in this article are included in the
article's Creative Commons license, unless indicated otherwise in the credit line; if the material is not included under the Creative Commons license, users will need to obtain permission from the license holder to reproduce the material. To view a copy of this license, visit http://creativecommons.org/licenses/by/4.0/ 